\title{
A Bayesian Network Based on the Differentiated Pedagogy to Generate Learning Object According to FSLSM
}

\author{
http://dx.doi.org/10.3991/ijes.v3i2.4363 \\ Yassine Zaoui Seghroucheni ${ }^{1}$, Mohammed Al Achhab ${ }^{2}$ and Badr Eddine El Mohajir ${ }^{1}$ \\ ${ }^{1}$ Faculty of Sciences, Tetouan, Morocco \\ 2 The National School of Applied Science, Tetouan
}

\begin{abstract}
In this paper we propose a model that generates learning objects in an adaptive learning system according to the Felder Silverman learning styles, based on the Bayesian networks and taking into consideration the recommendations of the differentiated pedagogy which requires creating multiple versions of the same learning object. The proposed model includes also correcting the non-learning paths which is the main reason behind the choice of versioning the learning objects.
\end{abstract}

Index Terms-Adaptive learning system; learning object; learning styles; learning path; differentiated pedagogy; Bayesian network.

\section{INTRODUCTION}

The adaptive learning systems are an important class of the e-learning systems, the significance position they gained in the field, is due primarily to the endless possibilities they offer in terms of personalizing learning path, according to the needs, prerequisites and more importantly the learning styles, which translate obviously to a more satisfactory results on the learner side. Most of the adaptive learning systems build a learner model based on the learner's characteristics. An adaptive learning system is able to provide specific learning object according to the model built previously which create at the end a specific learning path. Somehow the generated learning paths may not be the leading ones. This translates, assessment wise, with a negative result in the evaluation.

Through this paper, we propose a model that generates learning objects based on the Bayesian network, using the FSLSM [1] and based on the recommendations of the differentiated pedagogy [2] which advocate offering multiple versions of the same learning object [3], on which we will rely on to correct the non-leading paths.

This paper is organized as follows:

The first section is dedicated to the related work, then we will be discussing the Felder and Silverman learning style model in section 2. Later in section 3 we will explore the Index of Learning Style as seen by Felder and Silverman. The relationship between the Learning Objects and Learning Style will be seen in section 4 , then in section 5 we will discuss the differentiated pedagogy and how it will serve for the approach used in this paper. Next we present the adaptation model and the Bayesian network in section 6 and 7 in a row. Finally some conclusions are drawn in section 8

\section{RELATED WORK}

There are several approaches that fall into the direction of personalizing learning path and offering an adapted content to the learner's profiles, those works can be summarized into two categories:

The first category contains systems who tend to use implicit methods for identifying learning styles based mainly on the analysis [4], [5] and observation [6], [7] of the learners behaviors in the system, The reason behind this choice is to not overwork the learner by offering him multiple forms to fill. However those methods are not completely reliable given the fact that a learner can engage in other activities during the learning process which can be misleading for the designer.

The second category contains the content adaptation systems that use explicit methods for identifying learning styles by using e-questionnaires [8], [9], [10] or letting the learners express their preferences [11] personal characteristics [12] or using the FSLSM [1], [13]. In both cases the systems propose the same learning objects, and it's only a matter of suitable sequence for everyone.

None of those works presented above questioned at any stage the cognitive level of the learning object, it is assumed that the proposed learning objects are valid for all learners, and it's only a matter of appropriate order. That's why the authors in [3] presented a model of versioning the LO which we will be adopting and exploring through this paper. The reason behind this choice is to remedy the problem of non-leading paths, by offering the most relevant versions, as most computing systems are based upon the initial calculating of profiles, [14], [15] and do not offer any correction of learning paths in case of a failure in an assessment.

\section{FSLSM}

There are many models about learning styles in literature such as Kolb [16], Dunn \& Dunn [17], Honey \& Mumford [18], and Myers-Briggs [19]. This model is based on Felder and Silverman's Learning Styles Model, because of its applicability to e-learning and compatibility to the principles of interactive learning systems design [20].

Students learn in many way by seeing and hearing; reflecting and acting; reasoning logically and intuitively; memorizing and visualizing and drawing analogies and building mathematical models; steadily and in fits and 
starts [21]. The ways in which an individual characteristically acquires, retains, and retrieves information are collectively termed the individual's learning style [22]. In 1988 R. Felder and L.Silverman proposed a learning style model that classifies five dimensions of learning styles. Lately, inductive/deductive was excluded from the model, so now we deal only with four dimensions (Figure 1).

In Table I is how those dimensions are translated learning Wise.

\section{The IndeX Of LEARning STYLE}

The Index of Learning Styles (ILS) developed by Felder and Soloman, is a questionnaire of 44 items to identify learning styles according FSLSM. As mentioned earlier, each student has a personal preference for each dimension. These preferences are expressed with values ranging from +11 to -11 per dimension, with steps $+/-2$. This range has eleven questions that are asked for each dimension. In response to a question, for example, with an active preference, one is added to the value of the active / Reflective dimension while a response to a preference Reflective decreases the value of 1 . Therefore, each question is answered either with a value of 1 (answer a) or -1 (answer b). Answer a is a preference for the first pole of each dimension (active, sensing, visual, or sequential), answer $b$ is to the second pole of each dimension (Reflective, Intuitive, verbal or Global). The ILS is an index often used and well-studied to identify learning styles. Each learning style dimension seems to include different characteristics. In an empirical study [10], the groups of preferences within each dimension of FSLSM were analyzed and their relevance for each dimension was investigated. Table II shows the proposed groups as well as the related answers of ILS questions [23] for each group. A question may appear twice in the table, if the two possible answers to the question point to two different groups.

\section{The RELATIONSHIP BETWEen THE LEARNING OBJECTS AND THE LEARNING STYLES}

Based on the theoretical descriptions about leaning styles' characteristics of Felder-Soloman [23], and on the practical research of [24]-[25]-[26], the learning objects are labeled as described in Table III.

However more than one pedagogical activity might be shared between one or more learning styles as shown in Figure 2.

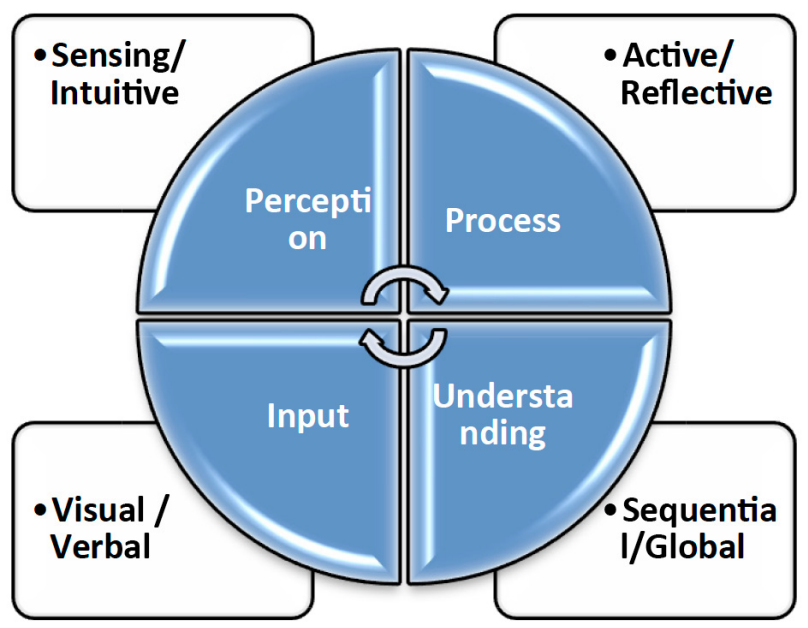

Figure 1. Dimensions of Felder and Silverman Learning Style Model
TABLE I.

THE PERCEPTION OF THE DIFFERENT LEARNING STYLES

\begin{tabular}{|c|c|}
\hline Dimension & Definition \\
\hline Active & Do it \\
\hline Reflective & Think about it \\
\hline Sensing & Learn facts \\
\hline Intuitive & Learn concepts \\
\hline Visual & Require pictures \\
\hline Verbal & Require reading or lecture \\
\hline Sequential & Step by step \\
\hline Global & Big picture \\
\hline
\end{tabular}

TABLE II.

THE ILS QUESTIONS ACCORDING TO LS

\begin{tabular}{cccccc}
\hline Style & $\begin{array}{c}\text { Semantic } \\
\text { group }\end{array}$ & $\begin{array}{c}\text { ILS } \\
\text { questions } \\
\text { (answer }\end{array}$ & Style & Semantic group & $\begin{array}{c}\text { ILS } \\
\text { ques- } \\
\text { tions } \\
\end{array}$ \\
& a) & & & (answer
\end{tabular}

\begin{tabular}{|c|c|c|c|c|c|}
\hline Active & $\begin{array}{c}\text { trying } \\
\text { something } \\
\text { out } \\
\text { Social } \\
\text { oriented }\end{array}$ & $\begin{array}{l}1,17,25, \\
29 \\
5,9,13, \\
21,33,37, \\
41\end{array}$ & $\begin{array}{l}\text { Reflec- } \\
\text { tive }\end{array}$ & $\begin{array}{l}\text { Think about } \\
\text { materiel } \\
\text { Impersonal } \\
\text { Oriented }\end{array}$ & $\begin{array}{l}1,5,17 \\
25,29 \\
9,13 \\
21,33 \\
41,37\end{array}$ \\
\hline Sensing & $\begin{array}{c}\text { Existing } \\
\text { ways } \\
\text { Concrete } \\
\text { material } \\
\text { Careful } \\
\text { with ideas }\end{array}$ & $\begin{array}{l}2,30,34 \\
6,10,14 \\
18,26,38 \\
22,42\end{array}$ & Intuitive & $\begin{array}{c}\text { new ways } \\
\text { abstract material } \\
\text { not careful with } \\
\text { details }\end{array}$ & $\begin{array}{l}2,14, \\
22,26, \\
30,34 \\
6,10, \\
18,38 \\
42\end{array}$ \\
\hline
\end{tabular}

\begin{tabular}{|c|c|c|c|c|c|}
\hline Visual & Pictures & $\begin{array}{l}3,7,11, \\
15,19,23, \\
27,31,35, \\
39,43\end{array}$ & Verbal & $\begin{array}{l}\text { spoken words } \\
\text { written words } \\
\text { difficulty with } \\
\text { visual style }\end{array}$ & $\begin{array}{l}3,7,15, \\
19,27, \\
35 \\
3,7,11, \\
23,31, \\
39 \\
43\end{array}$ \\
\hline $\begin{array}{c}\text { Se- } \\
\text { quentia } \\
l\end{array}$ & $\begin{array}{c}\text { detail } \\
\text { oriented } \\
\text { sequential } \\
\text { progress } \\
\text { from parts } \\
\text { to the } \\
\text { whole }\end{array}$ & $\begin{array}{l}4,28,40 \\
20,24,32 \\
36,44 \\
8,12,16\end{array}$ & Global & $\begin{array}{c}\text { overall picture } \\
\text { Non-sequential } \\
\text { progress } \\
\text { rela- } \\
\text { tions/connections }\end{array}$ & $\begin{array}{l}4,8,12, \\
16,28, \\
40 \\
24,32 \\
20,36, \\
44\end{array}$ \\
\hline
\end{tabular}

TABLE III.

THE LS-LO RELATIONSHIP

\begin{tabular}{|c|c|c|c|c|c|c|c|}
\hline $\begin{array}{l}\text { Ac- } \\
\text { tive }\end{array}$ & $\begin{array}{c}\text { Re- } \\
\text { flec- } \\
\text { tive }\end{array}$ & $\begin{array}{c}\text { Sens- } \\
\text { ing }\end{array}$ & $\begin{array}{c}\text { Intui- } \\
\text { tive }\end{array}$ & $\begin{array}{c}\text { Visu- } \\
\text { al }\end{array}$ & $\begin{array}{l}\text { Ver } \\
\text { bal }\end{array}$ & $\begin{array}{c}\text { Se- } \\
\text { quent } \\
\text { ial }\end{array}$ & $\begin{array}{c}\text { Glob } \\
\text { al }\end{array}$ \\
\hline $\begin{array}{l}\text { As- } \\
\text { sess- } \\
\text { ment } \\
\text { Exer- } \\
\text { cises, }\end{array}$ & $\begin{array}{c}\text { Exam } \\
\text { am- } \\
\text { ples, } \\
\text { out- } \\
\text { lines, } \\
\text { sum- } \\
\text { mar- } \\
\text { ies, } \\
\text { result } \\
\text { pages }\end{array}$ & $\begin{array}{c}\text { Exam- } \\
\text { am- } \\
\text { ples, } \\
\text { expla- } \\
\text { na- } \\
\text { tion, } \\
\text { facts, } \\
\text { prac- } \\
\text { tical } \\
\text { mate- } \\
\text { rial }\end{array}$ & $\begin{array}{l}\text { Defini } \\
\text { ni- } \\
\text { tions, } \\
\text { algo- } \\
\text { rithms }\end{array}$ & $\begin{array}{c}\text { Image } \\
\text { s, } \\
\text { gra- } \\
\text { phics, } \\
\text { charts } \\
\text {, } \\
\text { anima } \\
\text { ma- } \\
\text { tions, } \\
\text { vi- } \\
\text { deos }\end{array}$ & $\begin{array}{c}\text { Tex } \\
\text { t, } \\
\text { au- } \\
\text { dio }\end{array}$ & $\begin{array}{c}\text { Step } \\
\text { by } \\
\text { step } \\
\text { exer- } \\
\text { cises, } \\
\text { con- } \\
\text { strict } \\
\text { link } \\
\text { pages }\end{array}$ & $\begin{array}{c}\text { Out- } \\
\text { lines, } \\
\text { sum- } \\
\text { mar- } \\
\text { ies, } \\
\text { all- } \\
\text { Link } \\
\text { pages }\end{array}$ \\
\hline
\end{tabular}




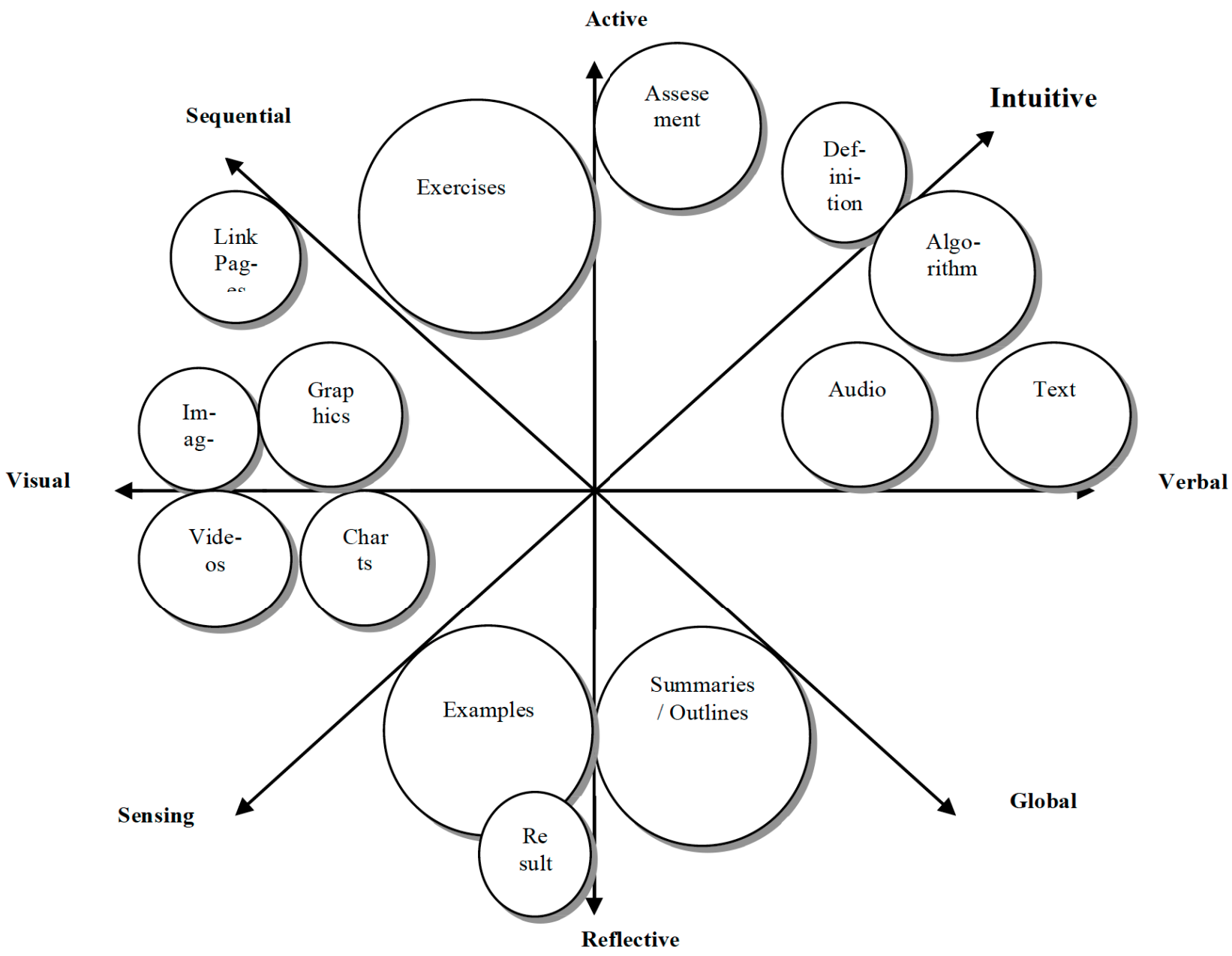

Figure 2. The tendencies of $\mathrm{LO}$ according to the LS

\section{VERSIONING ACCORDING TO THE DIFFERENTIATED PEDAGOGY}

To differentiate is to break with a pedagogy that is frontal, the same lessons, the same exercises etc...for all learners. The goal is to put everyone in an optimal learning situation. This organization is to use all the educational resources available so that each learner is constantly or at least very often confronted with the most fruitful teaching situation. The following part is based on the works of [3], in fact the authors chose to emphasize the following versions of every learning object presented in the system based on the recommendations of [2].

As the chart below (Figure 3) shows, there are 4 different versions for the same $\mathrm{LO}$ :

i. VM: a multimedia version.

ii. VR: a version with a reminder of the previous LO.

iii.VD: a version with a deeper level of knowledge.

iv. VA: a standard version.

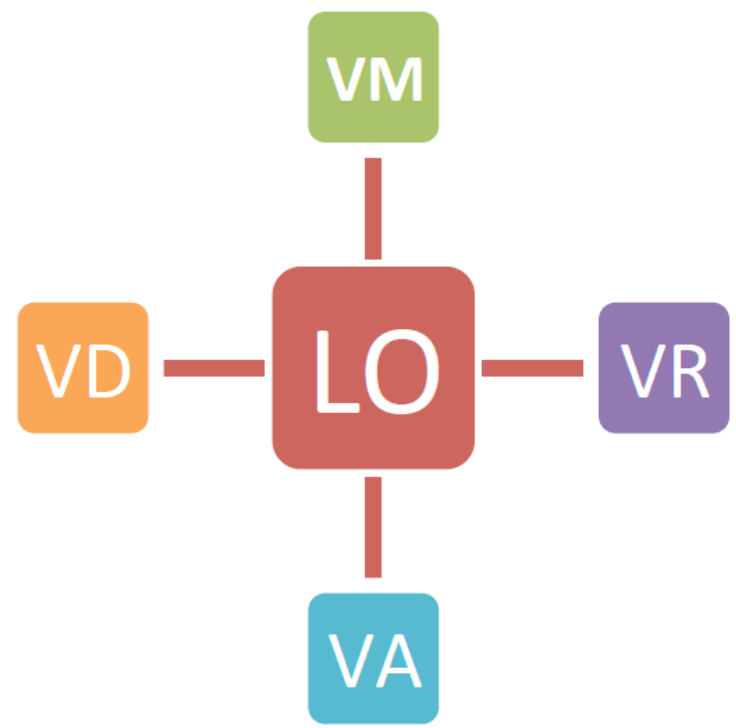

Figure 3. Versions of the same LO 


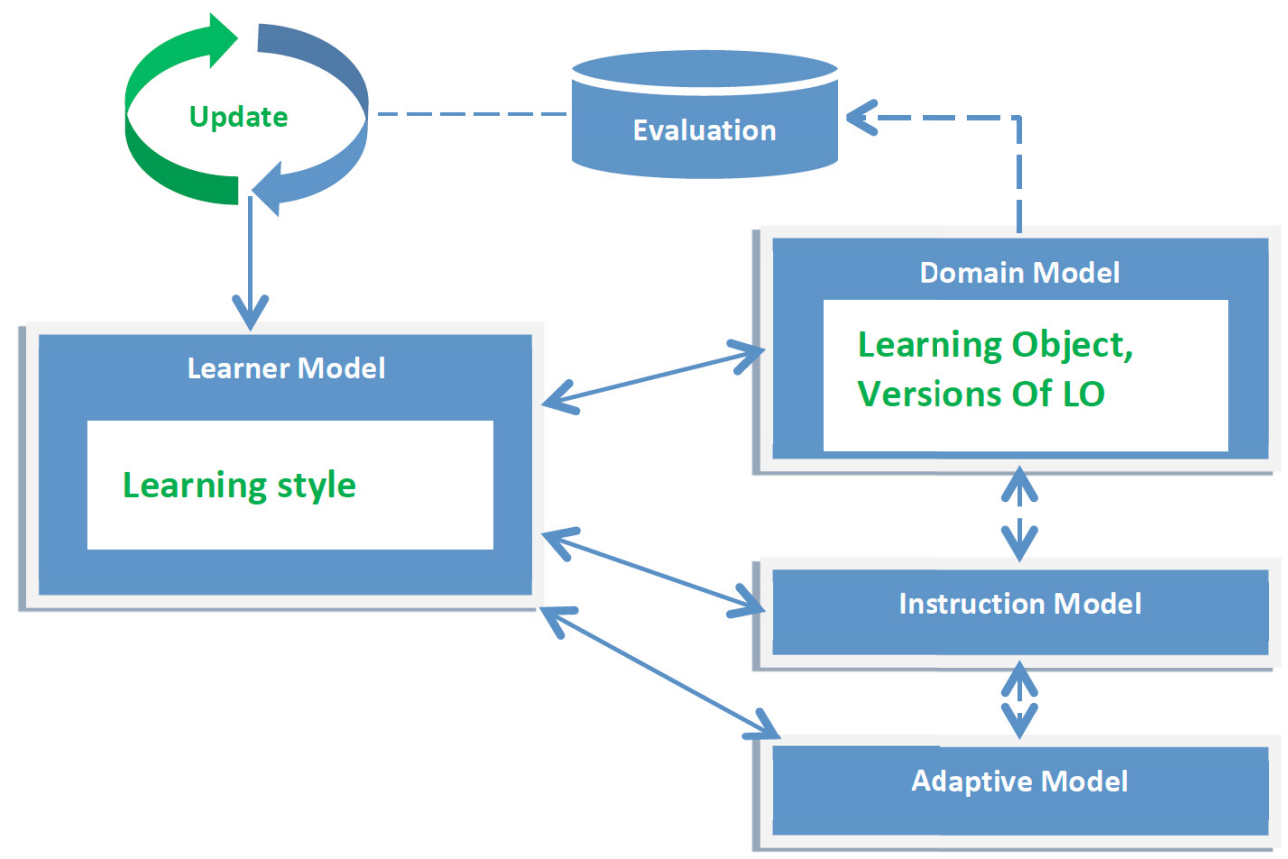

Figure 4. The adaptation model

\section{THE ADAPTATION MODEL}

In general, adaptive learning system is composed of Domain model, Learner model and the adaptive model (Figure 4). The adaptation model developed through this paper takes into account the following parameters:

Learner model: The learner model used is based on the Felder-Silverman learning styles, and the prerequisis of each learner,

Domain Model: The domain model is composed of the learning objects which are designed according to the SCORM Standards, a multiple versions of the same learning object and finally the Content metadata as defined by IEEE Learning object Metadata.

Instruction Model: The instruction model is the pedagogical model responsible for designing the learning object included in the domain object.

Adaptability model: The adaptation model is the one generating learning objects according to the characteristics of learners (prerequisis, learning styles) and the learning objects that match them. (See fig 2)

Evaluation: The evaluation is the critical part in this adaptive learning system as it remains the only way to correct learning paths if it appears that the generated learning path is not the leading one ( see section 10)

\section{The BAYESIAN NeTWORK MOdeL}

A Bayesian Network (BN) is a graphical model for efficiently representing a joint probability distribution over a set of random variables $\mathrm{V}$. A BN is denoted by $(\mathrm{G}, \mathrm{P})$; where $G$ is a Directed Acyclic Graph (DAG) defined over $\mathrm{V}$ (such graph encodes independence relationships among the variables in $\mathrm{V}$ ); and $\mathrm{P}$ denotes a set of local probability distributions, one for each variable conditioned on its parents. Variables are represented for nodes denoting "concepts" and edges indicating cause/effect dependencies among concepts. Final nodes can be seen as "effects" (values collected from the learning environments), while highest-level nodes can be thought as "causes". Every node can have two or more possible results; each result is named a state of the variable. Thus, once the learner's profile is defined (Learning style according to FelderSilverman and prerequisis) the learner model can be built.

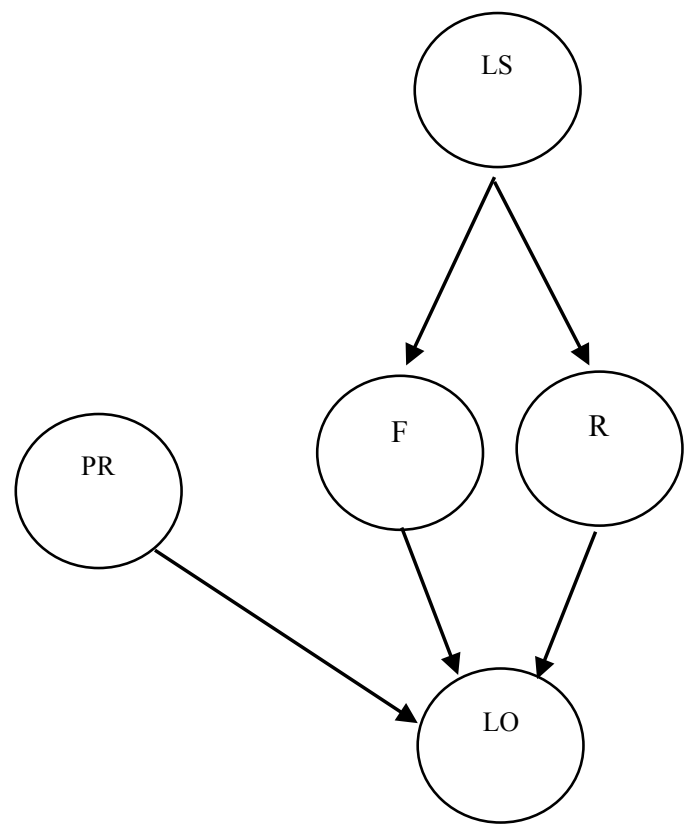

Figure 5. The Bayesian network generating the LO

$\mathrm{P}$ (PR), P (LS), are representing the A priori probabilities F: Learning object Format $=\{$ video, text, audio, picture $\}$ R: Learning object Unit $=\{$ exercise, example, outline... $\}$ PR: prerequisis $=\{$ Low, Average, High $\}$

The BN shown above enables creating the most suitable learning object for every learner while taking into consideration mostly his learning style and perquisites, the mathematic formula is given in the upcoming section right after discussing the learning styles combinations. 


\section{A. the learning styles combinations}

A learning style combination (LSC) is a 4-tuple composed by one learning Style from each FSLSM dimension:

$\mathrm{LSC}=\{(\mathrm{a}, \mathrm{b}, \mathrm{c}, \mathrm{d}) / \mathrm{a} \in \mathrm{D} 1 ; \mathrm{b} \in \mathrm{D} 2 ; \mathrm{c} \in \mathrm{D} 3 ; \mathrm{d} \in \mathrm{D} 4\}$ Where:

$\mathrm{D} 1=\{$ Active $(\mathrm{A}) ; \operatorname{Reflective}(\mathrm{R})\}$

$\mathrm{D} 2=\{$ Sensitive $(\mathrm{S}) ;$ Intuitive $(\mathrm{I})\}$

$\mathrm{D} 3=\{$ Visual $(\mathrm{V}$ i); Verbal $(\mathrm{Ve})\}$

$\mathrm{D} 4=\{$ Sequential $(\mathrm{Seq}) ;$ Global $(\mathrm{G})\}$

Therefore, there are 16 possible learning styles combinations:

$\mathrm{LSCs}=\{(\mathrm{A}, \mathrm{Vi}, \mathrm{S}, \mathrm{Seq}),(\mathrm{A}, \mathrm{Vi}, \mathrm{S}, \mathrm{G}),(\mathrm{R}, \mathrm{Vi}, \mathrm{S}, \mathrm{Seq})$,

(R,Vi,S,G), (A,Ve,S,Seq), (A,Ve,S,G),

(R,Ve,S,Seq), (R,Ve,S,G),(A,Vi,I,Seq), (A,Vi,I,G),

(R,Vi,I,Seq), (R,Vi,I,G), (A,Ve,I,Seq),

(A,Ve,I,G), (R,Ve,I,Seq), (R,Ve,I,G)\}.

Usually the values of learning styles are stored in the values $[-11 \ldots+11]$, but since we are using those values in a probabilistic context, those values will be stored in the interval $[0 \ldots 100]$

\section{- $\quad$ Learning Styles (LS)}

$\mathrm{LS}=\{(\operatorname{PrA} ; \operatorname{PrR}) ;(\operatorname{PrS} ; \operatorname{PrI}) ;(\operatorname{PrV}$ i; PrV e); (PrSeq;

PrG) $/$ PrA $+\operatorname{PrR}=100 ; \operatorname{PrS}+$

$\operatorname{PrI}=100 ; \operatorname{PrVi}+\operatorname{PrVe}=100 ; \operatorname{PrSeq}+\operatorname{PrG}=100\}$

$\mathrm{V}=\{\mathrm{VM}, \mathrm{VD}, \mathrm{VR}, \mathrm{VS}\}$

- $\quad$ Bayes' law

$\mathrm{P}(\mathrm{F} / \mathrm{LS})=\mathrm{P}(\mathrm{LS} / \mathrm{F}) \mathrm{P}(\mathrm{F}) / \mathrm{P}(\mathrm{LS})$

$\mathrm{P}(\mathrm{R} / \mathrm{LS})=\mathrm{P}(\mathrm{LS} / \mathrm{R}) \mathrm{P}(\mathrm{R}) / \mathrm{P}(\mathrm{LS})$

$\mathrm{P}(\mathrm{LO} / \mathrm{PR}, \mathrm{F}, \mathrm{D})=\mathrm{P}(\mathrm{PR}, \mathrm{F}, \mathrm{D} / \mathrm{LO}) \mathrm{P}(\mathrm{LO}) / \mathrm{P}(\mathrm{PR}, \mathrm{F}$, D)

\section{THE LEARNING PATH CORRECTION}

One of the major disadvantages of the Adaptive learning system discussed in the Related work section, is that they consider work done once they generate the suitable learning objects and as a result a learning path. However those learning path may not be the leading ones, which translates to a negative result on the learner's side. Of course the evaluation remains the only way to detect whether a specific path is the leading one or not.

Every evaluation has two outcomes, a positive or a negative result; we are interested with the negative one's case, since we intend to correct the learning path of the learner experiencing difficulties. In fact this correction is done by calculating the similarity between the struggling learner and the learners who have passed successfully the evaluation provided that they have the same initial profile. Those calculations are based on the behavioral indicators (NBREXR, NBREXM, NBRAST, DSB, TMPTH, FC, TEC, DP) developed by the authors of [27].

Each learner can be considered as an incomplete vector which we know only a few components. However, it is possible to calculate a similarity between such vectors by restricting to only components they have in common. Assuming that the behavior of learners $\mathrm{X}$ and $\mathrm{Y}$ are the variables (NBREXR, NBREXM, NBRAST, DSB, TMPTH, FC, TEC, DP) it is possible to define the correlation coefficient between $\mathrm{X}$ and $\mathrm{X}$ by the BravaisPearson formula.

where:

$$
\rho=\operatorname{Cov}_{x, y} / S_{x} S_{y}
$$

$\operatorname{Cov}_{\mathrm{x}, \mathrm{y}}=\left(\left(\mathrm{NBREXR}_{\mathrm{x}}-\mathrm{m}_{\mathrm{x}}\right)\left(\mathrm{NBREXR}_{\mathrm{y}}-\mathrm{m}_{\mathrm{y}}\right)+\right.$ $\left(\mathrm{NBREXM}_{\mathrm{x}}-\mathrm{m}_{\mathrm{x}}\right)\left(\mathrm{NBREXM}_{\mathrm{y}}-\mathrm{m}_{\mathrm{y}}\right)+\left(\mathrm{NBRAST}_{\mathrm{x}}-\mathrm{m}_{\mathrm{x}}\right)$ $\left(\mathrm{NBRAST}_{\mathrm{y}}-\mathrm{m}_{\mathrm{y}}\right)+\left(\mathrm{ORD}_{\mathrm{x}}-\mathrm{m}_{\mathrm{x}}\right)\left(\mathrm{ORD}_{\mathrm{y}}-\mathrm{m}_{\mathrm{y}}\right)+\left(\mathrm{TMPTH}_{\mathrm{x}}\right.$ $\left.-\mathrm{m}_{\mathrm{x}}\right)\left(\mathrm{TMPTH}_{\mathrm{y}}-\mathrm{m}_{\mathrm{y}}\right)+\left(\mathrm{FC}_{\mathrm{x}}-\mathrm{m}_{\mathrm{x}}\right)\left(\mathrm{FC}_{\mathrm{y}}-\mathrm{m}_{\mathrm{y}}\right)+\left(\mathrm{TCE}_{\mathrm{x}}-\mathrm{m}_{\mathrm{x}}\right)$ $\left.\left(\mathrm{TCE}_{\mathrm{y}}-\mathrm{m}_{\mathrm{y}}\right)+\left(\mathrm{DP}_{\mathrm{x}}-\mathrm{m}_{\mathrm{x}}\right)\left(\mathrm{Dp}_{\mathrm{y}}-\mathrm{m}_{\mathrm{y}}\right)\right) / 8$

$\mathrm{S}_{\mathrm{x}}=\left(\left(\text { NBREXR }_{\mathrm{x}^{-}} \mathrm{m}_{\mathrm{x}}\right)^{2}+\left(\text { NBREXM }_{\mathrm{x}}-\mathrm{m}_{\mathrm{x}}\right)^{2}+\right.$ $\left(\text { NBRAST }_{\mathrm{x}}-\mathrm{m}_{\mathrm{x}}\right)^{2}+\left(\mathrm{ORD}_{\mathrm{x}}-\mathrm{m}_{\mathrm{x}}\right)^{2}+\left(\mathrm{TMPTH}_{\mathrm{x}}-\mathrm{m}_{\mathrm{x}}\right)^{2}+$ $\left.\left(\mathrm{FC}_{\mathrm{x}}-\mathrm{m}_{\mathrm{x}}\right)^{2}+\left(\mathrm{TCE}_{\mathrm{x}}-\mathrm{m}_{\mathrm{x}}\right)^{2}+\left(\mathrm{DP}_{\mathrm{x}}-\mathrm{m}_{\mathrm{x}}\right)\right) / 8$

$\mathrm{S}_{\mathrm{y}}=\left(\left(\mathrm{NBREXR}_{\mathrm{y}}-\mathrm{m}_{\mathrm{y}}\right)^{2}+\left(\mathrm{NBREXM}_{\mathrm{y}}-\mathrm{m}_{\mathrm{y}}\right)^{2}+\left(\mathrm{NBRAST}_{\mathrm{y}}-\right.\right.$ $\left.\mathrm{m}_{\mathrm{y}}\right)^{2}+\left(\mathrm{ORD}_{\mathrm{y}}-\mathrm{m}_{\mathrm{y}}\right)^{2}+\left(\mathrm{TMPTH}_{\mathrm{y}}-\mathrm{m}_{\mathrm{y}}\right)^{2}+\left(\mathrm{FC}_{\mathrm{y}}-\mathrm{m}_{\mathrm{y}}\right)^{2}+\left(\mathrm{TCE}_{\mathrm{y}}-\right.$ $\left.\left.\mathrm{m}_{\mathrm{y}}\right)^{2}+\left(\mathrm{DP}_{\mathrm{y}}-\mathrm{m}_{\mathrm{y}}\right)\right) / 8$

If $(\rho>0,5)$

1. Recommend the versions of the learning objects of this specific learner (with whom the similarity is optimum)

If $(\rho<0,5)$

1. Search similarity with all the Learners.

2. Update the profile by editing the learning style of the struggling learner according to the similarity result.

\section{CONCLUSION}

Through this paper we presented a probabilistic approach for an adaptation model of learning objects based on the differentiated pedagogy and Felder-Silverman learning style model, using the Bayesian Network. The model operate mainly using the prerequisis and the learning style at the early stage, then by calculating the probability of suitability of every learning object to a learning style, this model also corrects the learning path in case of a negative result in an assessment, by offering the learner experiencing difficulties, the best learning path according to the similarity with the learner who has adopted the same behavior within the system. Later we intend to develop a method to eliminate from the system the most irrelevant learning objects or versions to avoid overloading the system with poorly used learning objects.

\section{REFERENCES}

[1] Felder, R.M. and L.K. Silverman, Learning Styles and Teaching Styles in Engineering Education, Presented at the 1987 Annual Meeting of the American Institute of Chemical Engineers, New York, Nov. 1987.

[2] Philippe Meiriu, Apprendre... oui, mais comment?, ESF éditeur, Paris, $1987,17^{\circ}$ edition, 1999.

[3] Seghroucheni, Y. Z., Mohammed, A., \& El Mohajir, B. E. (2014). An Approach to Create Multiple Versions of the Same Learning Object. International Journal of Emerging Technologies in Learning (iJET), 9(5), pp-17. http://dx.doi.org/10.3991/ijet.v9i5.3762 
[4] Vincenza Carchiolo and Alessandro Longheu and Michele Malgeri and Giuseppe Mangioni, An Architecture to Support Adaptive E-Learning, IJCSNS International Journal of Computer Science and Network Security, VOL.7 No.1, January 2007.

[5] Nabila Bousbia, Issam Reba, Jean-Marc Labat, Amar Balla, Analyzing the record Relationship between Learning Styles and Navigation Behavior in Web-Based Educational System, Knowledge Management ELearning: An International Journal, Vol.2, No.4. 400

[6] Silvia Schiaffino, Patricio Garcia, Analia Amandi, E-teacher providing personalized assistance to e-learning students? SISTAN Research Institute Fac. Cs. Exactas - UNCPBA, Campus Universitario, Paraje Arroyo Seco, 7000 Tandil, Buenos Aires, Argentina, 2008.

[7] Sabine Graf and Kinshuk Providing Adaptive Courses in Learning Management Systems with Respect to Learning Styles, Vienna University of Technology Women's Postgraduate College for Internet Technologies Vienna, Austria Athabasca.

[8] Paraskevi Tzouveli Phivos Mylonas, Stefanos Kollias, An intelligent e-learning system based on learner profiling and learning resources adaptation,National Technical University of Athens, School of Electrical and Computer Engineering, Athens, Greece Received 7 February 2007;received in revised form 4 May 2007; accepted 4 May 2007.

[9] Boyan Bontchev and Dessislava Vassileva Courseware Adaptation to learning styles and knowledge level, Department of Software Engineering, Sofia University, Sofia Bulgaria.

[10] Sabine Graf, Silvia Rita Viola,Tommaso Leo and Kinshuk InDepth Analysis of the Felder-Silverman Learning Style Dimensions, Journal of Research on Technology in Education, 2007, 40(1).

[11] Ana-Elena Guerrero-Roldn , Juli Minguilln Alfonso Adaptive learning paths for Improving lifelong learning experiences? Department of Computer Science, Universitat Oberta de Catalunya, Barcelona, Spain.

[12] Stphanie Jean-Daubias, Thi-Thu-Hong Phan, Different levels of modeling for learner profiles,

[13] Papanikolaou, KA , Grigoriadou, M., Kornilakis , H., Magoulas , GD (2003) Personalizing the interaction in a Web-based educational hypermedia system : the case of INSPIRE . User- Modeling and User -Adapted Interaction, 13, pp . 213-267. http://dx.doi.org/10.1023/A:1024746731130

[14] Vincenza Carchiolo and Alessandro Longheu and Michele Malgeri and Giuseppe Mangioni, An Architecture to Support Adaptive E-Learning, IJCSNS International Journal of Computer Science and Network Security, VOL.7 No.1, January 2007.

[15] Sampson, D., Karagiannidis, C., Cardinali, F, An Architecture for Webbased e-Learning Promoting Re-usable Adaptive Educational e-Content, Educational Technology Society 5 (4), 2002, ISSN 1436-4522.

[16] Kolb, A.Y., Kolb, D.A.: The Kolb Learning Style Inventory Version 3.1, Technical Specification. Hay Group, Boston (2005)
[17] Dunn, R., Dunn, K., Price, G.E.: Learning Style Inventory, Lawrence, KS. Price Systems (1996)

[18] Honey, P., Mumford, A.: The Learning Styles Helper's Guide. Peter Honey Publications Ltd., Maidenhead (2006)

[19] Myers, I.B., McCaulley, M.H.: Manual: A Guide to the Development and Use of the Myers-Briggs Type Indicator. Consulting Psychologists Press, Palo Alto (1998)

[20] Kuljis, J., Liu, F.: A Comparison of Learning Style Theories on the Suitability for Elearning. In: Hamza, M.H. (ed.) Proceedings of the Iasted Conference on Web Technologies,Applications, and Services, pp. 191-197. ACTA Press (2005)

[21] Felder, R., Silverman, L.: Learning and Teaching Styles. Journal of Engineering Education 94(1), 674-681 (1988)

[22] Felder, R., Henriques, E.R.: Learning and Teaching Styles In Foreign and Second Language Education. Foreign Language Annals 28(1), 21-31 (1995) http://dx.doi.org/10.1111/j.19449720.1995.tb00767.x

[23] B. A. Soloman and R. M. Felder. Index of Learning Styles. 1997. Available: http://www.engr.ncsu.edu/learningstyles/ilsweb.html

[24] S. Graf, Kinshuk, and T.C. Liu. Identifying Learning Styles in Learning Management Systems by Using Indications from Students' Behaviour. Proc. of the 8th IEEE International Conference on Advanced Learning Technologies. (ICALT'08). 2008, pp. 482486.

[25] Hong H. and Kinshuk. Adaptation to student learning styles in web based educational systems. Proc. of the World Conference on Educational Multimedia, Hypermedia \& Telecommunications (ED-MEDIA). 2004, pp. 491-496.

[26] E. Popescu, P. Trigano and C. Badica. Relations between Learning Style and Learner Behavior in an Educational Hypermedia System: an Exploratory Study. Proc. of the 8th IEEE International Conference on Advanced Learning Technologies, (ICALT'08). 2008, pp. 725-726. http://dx.doi.org/10.1109/icalt.2008.191

[27] Y.Z Seghroucheni, A.Mohammed and B.EL Mohajir, A Recommendation System Operating after Assessment to Correct Learning Paths in a Content Adapting System, International Journal of Computer Applications (0975 - 8887) Volume 93 - No.13, May 2014.

\section{AUTHORS}

Y. Z. Seghroucheni is with the Faculty of Sciences of Tetouan (e-mail: yassinezaouiseghroucheni@gmail.com).

M. AL Achhab, is with the National School of Applied Sciences of Tetouan (e-mail: alachhab@gmail.com).

B. E. El mohajir is the Faculty of Sciences of Tetouan (e-mail: b.elmohajir@ieee.ma)

Submitted 31 December 2014. Published as resubmitted by the authors 12 May 2015. 